\title{
MENINGKATKAN KEMAMPUAN SISWA MENULIS TEKS BERBENTUK PROCEDURE MELALUI MODEL PEMBELAJARAN MAKE A MATCH DI KELAS IX A SMP NEGERI 2 KARAU KUALA
}

\author{
Nasaruan Abadi \\ SMP Negeri 2 Karau Kuala, Jl. Barito Raya No. 021, Barito Selatan, Kalimantan Tengah, Indonesia \\ Email: nasaruana@gmail.com
}

\begin{abstract}
The objectived to be achieved in this study are to improve students' ability in compiling text procedures, developing learning strategies and learning models that are effective, efficient and fun. Students can be actively involved in communication activities by simply expressing their ideas, opinions and feelings both orally and writen. This classroom action research is conducted in class IX A SMP Negeri 2 Karau Kuala, South Barito Regency with a total of 30 students. In this research is researcher play a role concurrently as Model Teachers in collaboration with 1 English teacher who is part of a group of teachers who teaches class IX A. The research is conducted from August to September 2017. The tdata collection echnique used in this research is observation and giving student performance tests in the form of written tests. Finally, the author can obtain some findings after carrying out reflection and discussion in the previous chapter. Thus, this Classroom Action Research can be concluded such as follows: 1) The use of the Make a Match learning model can improve the abilities of class IX A students of SMP Negeri 2 Karau Kuala, South Barito Regency in semester 1 of the 2017/2018 school year. This can be proven through the evaluation / written test with the average score of students in the first cycle of 63.05 increasing in the second cycle to 69.73, and in the third cycle increasing to 77.71. 2) The use of the Make a Match learning model and video learning media can improve student learning activities. This can be proven by the percentage of student activeness in the first cycle of $36.67 \%$, increasing in the second cycle to $80.00 \%$, and in the third cycle to $100 \%$.
\end{abstract}

Keywords: Writing Procedure Shaped Text, Make a Match Learning Model

\begin{abstract}
ABSTRAK
Tujuan yang ingin di capai dalam penelitian ini adalah meningkatkan kemampuan siswa untuk menyusun teks procedure, mengembangkan strategi pembelajaran dan model pembelajaran yang efektif, efisien dan menyenangkan. Siswa dapat melibatkan diri secara aktif dalam kegiatan komunikasi dengan mengemukakan gagasan, pendapat dan perasaannya secara sederhana baik lisan maupun tulisan. Penelitian tindakan kelas ini dilaksanakan di kelas IX A SMP Negeri 2 Karau Kuala Kabupaten Barito Selatan dengan jumlah siswa sebanyak 30. Pada pelaksanaannya, peneliti sekaligus berperan sebagai Guru Model berkolaborasi dengan1 orang guru Bahasa Inggris yang tergabung dalam kelompok guru yang mengajar di kelas IX A. Penelitian dilaksanakan pada Bulan Agustus sampai dengan September 2017. Teknik pengumpulan data dilakukan melalui observasi dan pemberian test performance siswa dalam bentuk test tulis. Akhirnya, penulis dapat memperoleh beberapa hasil temuan setelah melaksanakan refleksi dan diskusi pada bab sebelumnya. Penelitian Tindakan Kelas ini dapat disimpulkan sebagai berikut: 1) Penggunaan Model Pembelajaran Make a Match dapat meningkatkan kemampuan siswa kelas IX A SMP Negeri 2 Karau Kuala Kabupaten Barito Selatan pada semester 1 tahun pelajaran 2017/2018. Hal tersebut dapat dibuktikan melalui evaluasi/ test tulis dengan rata-rata nilai siswa pada siklus pertama 63,05 meningkat pada siklus II menjadi 69,73, dan pada siklus III meningkat menjadi 77,71; 2) Penggunaan Model Pembelajaran Make a Match dan media pembelajaran video dapat meningkatkan aktifitas belajar siswa. Hal tersebut dapat dibuktikan dengan persentase keaktifan siswa pada siklus pertama sebesar $36,67 \%$ meningkat pada siklus kedua menjadi $80,00 \%$ dan pada siklus III menjadi $100 \%$.
\end{abstract}

Kata Kunci: Menulis Teks Berbentuk Procedure, Model Pembelajaran Make a Match

Cara sitasi: Abadi, N. (2020). Meningkatkan Kemampuan Siswa Menulis Teks Berbentuk Procedure Melalui Model Pembelajaran Make a Match di Kelas IX A SMP Negeri 2 Karau Kuala. J-KIP (Jurnal Keguruan dan IImu Pendidikan), 1 (2), 91-98. 


\section{PENDAHULUAN}

Secara umum Bahasa Inggris memiliki peran sentral dalam perkembangan intelektual, sosial, dan emosional peserta didik dan merupakan penunjang keberhasilan dalam mempelajari semua bidang studi. Pembelajaran bahasa diharapkan membantu peserta didik mengenal dirinya, budayanya, dan budaya orang lain. Selain itu, pembelajaran bahasa juga membantu peserta didik mampu mengemukakan gagasan dan perasaan, berpartisipasi dalam masyarakat, dan bahkan menemukan serta menggunakan kemampuan analitis dan imaginatif yang ada dalam dirinya.

Ruang lingkup mata pelajaran Bahasa Inggris di SMP meliputi kemampuan berwacana, yakni kemampuan memahami dan/atau menghasilkan teks lisan dan/atau tulis yang direalisasikan dalam empat keterampilan berbahasa, yakni mendengarkan, berbicara, membaca dan menulis secara terpadu untuk mencapai tingkat literasi functional; dan juga kemampuan memahami dan menciptakan berbagai teks fungsional pendek dan monolog serta esei berbentuk narrative, explanation, dan discussion. Gradasi bahan ajar tampak dalam penggunaan kosa kata, tata bahasa, dan langkah-langkah retorika.

Tingkat literasi mencakup performative, functional, informational, dan epistemic. Pada tingkat performative, orang mampu membaca, menulis, mendengarkan, dan berbicara dengan simbol-simbol yang digunakan. Pada tingkat functional, orang mampu menggunakan bahasa untuk memenuhi kebutuhan hidup sehari-hari seperti membaca surat kabar, manual atau petunjuk. Pada tingkat informational, orang mampu mengakses pengetahuan dengan kemampuan berbahasa, sedangkan pada tingkat epistemic orang mampu mengungkapkan pengetahuan ke dalam bahasa sasaran (Wells,1987).

Penguasaan kemampuan Bahasa Inggris (language skill) merupakan sebuah syarat mutlak yang harus dimiliki di era komunikasi dan globalisasi saat ini. Pembelajaran Bahasa Inggris (Language Learning) di jenjang SMP merupakan materi pokok sebagai bagian dari fungsi pengembangan diri siswa dalam bidang IImu Pengetahuan, teknologi dan seni yang diharapkan setelah menamatkan studi, Mereka mampu tumbuh dan berkembang menjadi individu yang cerdas, terampil dan berkepribadian sebagai bekal hidup di masa mendatang.

Penguasan materi pelajaran Bahasa Inggris dalam jenjang SMP meliputi empat keterampilan berbahasa, yaitu: menyimak, berbicara, membaca dan menulis. Semua itu didukung oleh unsur-unsur bahasa lainnya, yaitu: Kosa Kata, Tata Bahasa dan Pronunciation sesuai dengan tema sebagai alat pencapai tujuan. Dari ke empat keterampilan berbahasa di atas, Writing (menulis) merupakan salah satu kemampuan berbahasa yang dirasa sering menjadi masalah bagi siswa dalam proses pembelajaran Bahasa Inggris. Hal tersebut sangat menarik untuk diteliti mengingat kemampuan menulis (writing ability) sangatlah dipengaruhi oleh penguasaan kosa kata, struktur bahasa dan kemampuan siswa dalam merangkai kata menjadi sebuah teks yang berterima. Perbedaan secara grammatical antara bahasa Inggris sebagai bahasa asing dan bahasa Indonesia sebagai bahasa utama merupakan masalah yang sering timbul pada saat belajar menulis. Kemampuan mengungkapkan makna dalam langkah retorika dalam essai pendek sederhana dengan menggunakan ragam bahasa tulis secara akurat, lancar dan berterima untuk berinteraksi dalam konteks kehidupan sehari-hari dalam teks berbentuk narrative, explanation, dan discussion adalah salah satu Kompetensi Dasar (KD) yang harus dikuasai oleh siswa Kelas IX Sekolah Menengah Pertama (SMP).

Pembelajaran mengungkapkan makna dalam langkah retorika dalam essai pendek sederhana dengan menggunakan ragam bahasa tulis secara akurat, lancar dan berterima untuk berinteraksi dalam konteks kehidupan sehari-hari dalam teks berbentuk narrative, explanation, dan discussion telah penulis lakukan secara klasikal. Dalam pembelajaran tersebut penulis menjelaskan materi pokok yang terdapat dalam indikator yaitu menyusun kalimat acak menjadi teks yang padu berbentuk narrative, explanation, dan discussion. 
Dalam kegiatan inti pembelajaran, siswa biasanya diberi contoh teks monolog berbentuk narrative, explanation, dan discussion dan siswa diminta untuk mencari arti dari teks tersebut yang kemudian dirangkai menjadi sebuah kalimat yang benar. Proses pembelajaran seperti itu sudah biasa dilakukan oleh penulis dan ternyata hasil pembelajaran siswa tidak sesuai yang diharapakan dan siswa masih dibawah Kriteria Ketuntasan Minimal (KKM). Penulis memperoleh data dari hasil pengamatan melalui refleksi yang dilakukan bahwa siswa terlihat pasif, bosan dan bahkan ada beberapa siswa yang mengeluh tidak percaya diri dalam mengungkapkan ide atau gagasannya. Mereka tentunya kesulitan dalam mengerjakan tugas yang diberikan oleh guru. Hal ini sangat mengundang pertanyaan dan asumsi bahwasannya metode pembelajaran tersebut tidak berhasil (gagal) dan cenderung tidak efektif.

Setelah mengamati uraian tersebut, dapat dilihat sebuah gambaran kegagalan terhadap hasil dan proses belajar dan hal tersebut merupakan masalah yang harus segera diatasi. Sebagai upaya memperbaiki kegagalan tersebut maka digunakan metode dan strategi pembelajaran yang tepat sebagai solusi selanjutnya (Djamarah, 2002). Penulis sadar bahwa di era Kurikulum Tingkat Satuan Pendidikan ini, guru dituntut untuk kreatif dan inovatif. Guru harus mampu mencari satu teknik pembelajaran yang sesuai dengan situasi dan kondisi kelas (Mulyasa, 2003). Prinsip PAIKEM (Pembelajaran Aktif, Inovatif, Kreatif, Efektif dan Menyenangkan) harus dilaksanakan (Hamalik, 2003). Guru bukan lagi merupakan sosok yang ditakuti dan bukan pula sosok otoriter, tetapi guru harus jadi seorang fasilitator dan motor yang mampu memfasilitasi dan menggerakkan siswanya untuk mendapatkan ilmu pengetahuan yang mereka butuhkan.

Setelah mengikuti pelatihan guru melalui MGMP BERMUTU (Better Education Through Reformed Management and Universal Teachers Upgrading) yang diselenggarakan oleh Dinas Pendidikan Kabupaten Barito Selatan, serta pengalaman penulis saat mengikuti berbagai pelatihan dan pendidikan, penulis mencoba menggunakan pendekatan Contextual Teaching And Learning dan pendekatan Cooperative Learning dengan menggunakan model pembelajaran Make a Match. Berdasarkan latar belakang yang telah dipaparkan, maka masalah yang diangkat dalam penelitian ini adalah: "Apakah melalui Penggunaan Model Pembelajaran Make a Match dapat meningkatkan Kemampuan Siswa Untuk Menyusun Teks Berbentuk narrative di kelas IX A SMP Negeri 2 Karau Kuala Kabupaten Barito Selatan?"

\section{METODE PENELITIAN}

Penelitian tindakan kelas ini dilaksanakan di SMP Negeri 2 Karau Kuala Kabupaten Barito Selatan. Alamat sekolah di Jl. Barito Raya No. 021 Tlp 081348294560 Bangkuang Kalteng 73761. Penelitian ini merupakan penelitian yang dilakukan melalui MGMP program BERMUTU yang pada pelaksanaannya peneliti sebagai Guru Model berkolaborasi dengan 3 orang Guru Bahasa Inggris. Subyek penelitian yang di ambil adalah kelas IX A SMP Negeri 2 Karau Kuala Kabupaten Barito Selatan. Waktu pelaksanaan dimulai dari bulan Agustus sampai dengan September 2017.

Kelas IX-A berjumlah 30 orang siswa dengan latar belakang sosial-ekonomi yang berbeda. Buku-buku pembelajaran yang dimiliki sendiri masih terbatas. Kemampuan akademik siswa masih terbatas karena motivasi belajar siswa yang rendah. Situasi kelas saat pembelajaran masih belum optimal, siswa masih belum seluruhnya mempunyai keaktifan dalam belajar.

\section{HASIL DAN PEMBAHASAN}

Penelitian ini dilaksanakan dengan tiga siklus mengacu pada pendapat Kemmis \& Taggart (1988). Rician dari kegiatan tiap siklusnya adalah sebagai berikut:

\section{SIKLUS I}

\section{Tahap Perencanaan (Planning), mencakup:}

1. Menganalisis Silabus/ Kurikulum Tingkat Satuan Pendidikan 
2. Menyusun Rencana Pelaksanaan Pembelajaran dengan metode CTL dengan menggunakan model Pembelajaran Make a Match.

3. Merancang model pembelajaran klasikal.

4. Mendiskusikan penerapan model pembelajaran interaktif.

5. Menyiapkan instrumen (angket, pedoman observasi, tes akhir).

6. Menyusun kelompok belajar peserta didik.

7. Merencanakan tugas kelompok.

Tahap Melakukan Tindakan (Action), mencakup:

1. Melaksanakan langkah-langkah sesuai perencanaan.

2. Menerapkan model pembelajaran klasikal.

3. Melakukan pengamatan terhadap setiap langkah-langkah kegiatan sesuai rencana.

4. Memperhatikan alokasi waktu yang ada dengan banyaknya kegiatan yang dilaksanakan.

5. Mengantisipasi dengan melakukan solusi apabila menemui kendala saat melakukan tahap tindakan.

Tahap Mengamati (observation), mencakup:

1. Melakukan diskusi dengan guru Bahasa Inggris MGMP Bahasa Inggris SMP Negeri 2 Karau Kuala Kabupaten Barito Selatan dan kepala sekolah untuk rencana observasi.

2. Melakukan pengamatan terhadap penerapan model pembelajaran klasikal yang dilakukan guru IX-A.

3. Mencatat setiap kegiatan dan perubahan yang terjadi saat penerapan model pembelajaran klasikal.

4. Melakukan diskusi dengan guru untuk membahas tentang kelemahan-kelemahan atau kekurangan yang dilakukan guru serta memberikan saran perbaikan untuk pembelajaran berikutnya.

Tahap refleksi (Reflection), mencakup:

1. Menganalisis temuan saat melakukan observasi pelaksanaan observasi.

2. Menganalisis kelemahan dan keberhasilan guru saat menerapkan model pembelajaran klasikal dan mempertimbangkan langkah selanjutnya.

3. Melakukan refleksi terhadap penerapan model pembelajaran klasikal.

4. Melakukan refleksi terhadap kreativitas peserta didik dalam pembelajaran Bahasa Inggris.

5. Melakukan refleksi terhadap hasil belajar peserta didik.

SIKLUS II

Tahap Perencanaan (Planning), mencakup:

1. Mengevaluasi hasil refleksi, mendiskusikan, dan mencari upaya perbaikan untuk diterapkan pada pembelajaran berikutnya.

2. Mendata masalah dan kendala yang dihadapi saat pembelajaran.

3. Merancang perbaikan berdasarkan refleksi siklus 1.

Tahap Melakukan Tindakan (Action), mencakup:

1. Melakukan analisis pemecahan masalah.

2. Melaksanakan tindakan perbaikan dengan menggunakan penerapan model pembelajaran Make a Match.

Tahap Mengamati (observation), mencakup:

1. Melakukan pengamatan terhadap penerapan model pembelajaran Make a Match.

2. Mencatat perubahan yang terjadi.

3. Melakukan diskusi membahas masalah yang dihadapi saat pembelajaran dan memberikan balikan.

Tahap Refleksi (Reflection), mencakup:

1. Merefleksikan proses pembelajaran Make a Match

2. Merefleksikan hasil belajar peserta didik dengan penerapan model pembelajaran Make a Match. 
3. Menganalisis temuan dan hasil akhir penelitian.

4. menyusun rekomendasi.

Dari tahap kegiatan pada siklus 1 dan 2, hasil yang diharapkan adalah agar (1) peserta didik memiliki kemampuan dan kreativitas serta selalu aktif terlibat dalam proses pembelajaran Bahasa Inggris; (2) guru memiliki kemampuan merancang dan menerapkan model pembelajaran interaktif dengan kerja kelompok khusus pada mata pelajaran Bahasa Inggris, dan (3) terjadi peningkatan prestasi peserta didik pada mata pelajaran Bahasa Inggris.

\section{SIKLUS III}

\section{Tahap Perencanaan (Planning), mencakup:}

1. Mengevaluasi hasil refleksi, mendiskusikan, dan mencari upaya perbaikan untuk diterapkan pada pembelajaran berikutnya.

2. Mendata masalah dan kendala yang dihadapi saat pembelajaran.

3. Merancang perbaikan berdasarkan refleksi siklus 1.

Tahap Melakukan Tindakan (Action), mencakup:

1. Melakukan analisis pemecahan masalah.

2. Melaksanakan tindakan perbaikan dengan menggunakan penerapan model pembelajaran Make a Match.

Tahap Mengamati (observation), mencakup:

1. Melakukan pengamatan terhadap penerapan model pembelajaran Make a Match.

2. Mencatat perubahan yang terjadi.

3. Melakukan diskusi membahas masalah yang dihadapi saat pembelajaran dan memberikan balikan.

Tahap Refleksi (Reflection), mencakup:

1. Merefleksikan proses pembelajaran Make a Match

2. Merefleksikan hasil belajar peserta didik dengan penerapan model pembelajaran Make a Match.

3. Menganalisis temuan dan hasil akhir penelitian.

4. Menyusun rekomendasi.

Data hasil analisis penilaian proses dan test tulis sebagai instrumen evaluasi yang telah di refleksikan dapat dilihat bahwa pada siklus ke 1 pembelajaran menyusun kalimat menjadi teks narative menggunakan model pembelajaran Make a Match tidak berhasil secara maksimal karena hasil tes dan proses tidak mencapai nilai yang diharapkan. Hal ini dapat ditemukan sebanyak 11 orang $(36,67 \%)$ siswa saja yang secara aktif mengikuti pelajaran sesuai dengan harapan. Sedangkan mayoritas siswa, yaitu sebanyak 19 orang $(63,33 \%)$ siswa masih terlihat pasif dalam proses pembelajaran menggunakan model pembelajaran Make a Match. Nilai yang diperoleh siswa pun belum menunjukkan hasil yang signifikan, bahkan dalam indikator mengidentifikasi generic structure dan language feature tidak ada satu siswa pun yang memperoleh nilai $A$ (excellent). Mayoritas siswa, atau sebanyak 18 orang $(0,60)$ mendapat nilai $E$ (poor), tidak ada orang mendapat nilai $B$ (Very Good), satu orang siswa $(0,03 \%)$ mendapat nilai $C($ Good), tujuh orang siswa $(0,23 \%)$ mendapat nilai $D$ (fair). Dengan kata lain implementasi tindakan pada siklus I tidak berhasil dan dapat dikatakan pembelajaran tersebut mengalami kegagalan dan diperbaiki di siklus II.

Pada tindakan siklus II guru mulai melakukan beberapa perbaikan dari kelemahan tindakan pembelajaran. Kelemahan yang ditemukan dalam siklus I meliputi media pembelajaran yang kurang relevan, siswa belum terbiasa/ belum akrab dengan mode pembelajaran Make a Match, serta pembatasan alokasi waktu tiap tahapan belajar yang kurang diperhatikan oleh guru. Hal tersebut menjadi dasar perbaikan di siklus II. Pada siklus III guru kemudian memperbaikinya dengan menggunakan media video berupa film yang menyajikan tata cara/ prosedur menggunakan mesin ATM, siswa terlihat antusias dan fokus pada proses pembelajaran. Selain itu, guru membagikan kartu ke tiap kelompok masing-masing, satu siswa mendapat satu buah kartu untuk di cocokkan dengan 
teman satu kelompok. Batasan waktu dan penjelasan permainan Make a Match juga disampaikan oleh guru.

Setelah melaksanakan tindakan siklus III, hasil pengamatan mengindikasikan bahwa 30 siswa $(100 \%)$ terlihat aktif dalam proses pembelajaran. Nilai siswa hasil dari evaluasi test tulis semua siswa sudah mencapai KKM (kriteria ketuntasan minimal). Nilai post test siswa berupa evaluasi individu melalui Lembar Kerja Siswa menunjukan sebanyak 17 siswa (0,56\%) mendapat nilai C 'good', 11 siswa $(0,36 \%)$ mendapat nilai $D$ 'fair'. Dengan demikian hasil pelaksanaan tindakan siklus III telah mengalami kenaikan yang cukup signifikan, walaupun peneliti belum merasa puas akan hasil yang telah ditemukan. Kenaikan hasil belajar siswa dapat dilihat dalam Tabel 1.

Tabel 1. Peningkatan Hasil Proses Pembelajaran

\begin{tabular}{lccc}
\hline Aktifitas Siswa & Siklus I & Siklus II & Siklus III \\
\hline Prosentase keaktifan siswa dalam pembelajaran & $36,67 \%$ & $80,00 \%$ & 100 \\
& & & \\
\hline
\end{tabular}

Berdasarkan Tabel 1 terlihat bahwa peningkatan hasil proses pembelajaran dari siklus 1 ke siklus 2 mengalami peningkatan dan pada siklus 3 terjadi peningkatan sebesar $100 \%$. Selanjutnya peningkatan hasil tes siswa disajikan pada Tabel 2.

Tabel 2. Peningkatan Hasil Test Siswa

\begin{tabular}{llll}
\hline Aktifitas Siswa & Siklus I & Siklus II & Siklus III \\
\hline Prosentase Siswa yang melebihi KKM $(\geq 70)$ & $36,67 \%$ & $80,00 \%$ & $100 \%$ \\
Hasil Rata-rata Nilai Test Writing & 63,05 & 69,73 & 77,71 \\
\hline
\end{tabular}

Berdasarkan penjelasan pada pembahasan diatas dapat diambil kesimpulan bahwa tujuan penelitian yang telah dilaksanakan mengalami keberhasilan sesuai dengan pendapat Arikunto (2005). Dengan kata lain, implimentasi tindakan pembelajaran melalui model pembelajaran Make a Match dapat meningkatkan kemampuan siswa dalam menulis teks berbentuk narative dan meningkatkan aktifitas siswa dalam proses pembelajaran.

Tindakan yang digunakan untuk mengatasi pembelajaran Writing agar dapat menarik, siswa menjadi termotivasi, minat belajar siswa tinggi adalah dengan metode pembelajaran kooperatif. Dengan optimalisasi pembelajaran Bahasa Inggris melalui Teknik Kooperatif merupakan alternatif proses pembelajaran agar lebih menyenangkan dan bermakna. Dalam hal ini penulis menggunakan model pembelajaran Make a Match.

Teknik metode pembelajaran Make a Match atau mencari pasangan dikembangkan oleh Curran (1994). Salah satu keunggulan tehnik ini adalah siswa mencari pasangan sambil belajar mengenai suatu konsep atau topik dalam suasana yang menyenangkan. Lie (2005) menyebutkan langkah-langkah penerapan metode Make a Match sebagai berikut:

1. Guru menyiapkan beberapa kartu yang berisi beberapa konsep atau topik yang cocok untuk sesi review, satu bagian kartu soal dan bagian lainnya kartu jawaban.

2. Setiap siswa mendapatkan sebuah kartu yang bertuliskan soal/jawaban.

3. Setiap siswa mencari pasangan kartu yang cocok dengan kartunya. Pemegang kartu yang bertuliskan penggalan kalimat prosedur $\mathrm{A}$ akan berpasangan dengan kalimat berikutnya yang dipegang oleh siswa di kelompok lain yang memegang kalimat narrative $B$ dan seterusnya.

4. Setiap siswa yang dapat mencocokkan kartunya sebelum batas waktu diberi poin.

5. Jika siswa tidak dapat mencocokkan kartunya dengan kartu temannya (tidak dapat menemukan kartu soal atau kartu jawaban) akan mendapatkan hukuman, yang telah disepakati bersama. 
6. Setelah satu babak, kartu dikocok lagi agar tiap siswa mendapat kartu yang berbeda dari sebelumnya, demikian seterusnya.

7. Siswa juga bisa bergabung dengan 2 atau 3 siswa lainnya yang memegang kartu yang cocok.

8. Guru bersama-sama dengan siswa membuat kesimpulan terhadap materi pelajaran.

\section{KESIMPULAN}

Penulis memperoleh beberapa hasil temuan setelah melaksanakan refleksi dan diskusi pada bab sebelumnya dan Penelitian Tindakan Kelas ini dapat disimpulkan sebagai berikut:

1. Penggunaan Model Pembelajaran Make a Match dapat meningkatkan kemampuan siswa kelas IX A SMP Negeri 2 Karau Kuala Kabupaten Barito Selatan. Hal tersebut dapat dibuktikan melalui evaluasi/ test tulis dengan rata-rata nilai siswa pada siklus pertama 63,05 meningkat pada siklus II menjadi 69,73 dan pada siklus III meningkat menjadi 77,71.

2. Penggunaan Model Pembelajaran Make a Match dan media pembelajaran video dapat meningkatkan aktifitas belajar siswa. Hal tersebut dapat dibuktikan dengan prosentase keaktifan siswa pada siklus pertama sebesar $36,67 \%$ meningkat pada siklus kedua menjadi $80,00 \%$ dan pada siklus III menjadi $100 \%$.

Dalam penelitian ini, berdasarkan hasil refleksi kedua siklus, peneliti membuat catatan beberapa saran untuk perbaikan di masa mendatang sebagaimana berikut:

1. Perhatian guru terhadap peningkatan mutu pendidikan Bahasa Inggris khususnya perlu ditingkatkan demi keberhasilan siswa dalam pembelajaran. Keterampilan menulis sangat essensial dihubungkan dengan aspek pengembangan diri siswa ke depan.

2. Model pembelajaran yang variatif hendaknya selalu dicoba sebagai upaya menciptakan proses pembelajaran aktif, inovatif, komunikatif, efektif dan menyenangkan sesuai dengan prinsip PAIKEM.

3. Guru hendaknya mengembangkan model pembelajaran yang efektif, efisien dan menyenangkan yang dapat melibatkan siswa secara aktif dalam proses pembelajaran Bahasa Inggris untuk meningkatkan kompetensi menulis mereka.

4. Dalam upaya membantu memperbaiki / meningkatkan proses hasil belajar dan mengajar guru hendaknya terus menggali potensi siswa guna meningkatkan kemampuan siswa dalam menulis (writing) teks bahasa Inggris.

\section{REKOMENDASI}

Proses pembelajaran yang baik dan menyenangkan adalah hal yang semestinya diciptakan oleh guru dalam membimbing dan memberi penguatan kepada siswa di kelas. Guru tentunya memiliki keinginan bagaimana siswa dapat dengan cepat mengerti dan mengaplikasikan apa yang menjadi tujuan pembelajaran. Hal yang paling utama adalah guru hendaknya senantiasa melakukan pengamatan sejauh mana peningkatan belajar siswa di kelas.

\section{UCAPAN TERIMAKASIH}

Ucapan terima kasih ditujukan kepada kepala SMP Negeri 2 Karau Kuala dan 3 orang Guru Bahasa Inggris yang telah mendukung terhadap pelaksanaan penelitian ini. Selanjutnya terima kasih juga ditujukan kepada subyek penelitian yaitu kelas IX A SMP Negeri 2 Karau Kuala Kabupaten Barito Selatan tahun pelajaran 2017/2018.

\section{DAFTAR PUSTAKA}

Arikunto, S. (2005). Penelitian Tindakan Kelas. Jakarta: Dirjen PMPTK.

Curran, L. (1994). Metode Pembelajaran Make a Match. Jakarta: Pustaka Belajar. 
Djamarah. (2002). Strategi Belajar mengajar. Jakarta : PT. Rineka Cipta.

Hamalik, O. (2003). Proses Belajar Mengajar. Jakarta : PT. Bumi Aksara.

Kemmis, S. \& Taggart, R. (1988). The Action Research Planner. Deakin: Deakin University.

Lie, A. (2005). Cooperative Learning. Jakarta: PT. Gramedia.

Mulyasa. (2003). Kurikulum Berbasis Kompetensi, Konsep, Karakteristik dan Implementasi. Bandung: Remaja Rosda karya.

Wells, A. (1987). Social Representation and the World of Science. Journal of the Theory of Social Behaviour, 17 (4), $433-455$. 